\title{
Influence of pre-germination treatments and temperature on the germination of crambe seeds (Crambe abyssinica Hochst)
}

\author{
Influência de tratamentos pré-germinativos e de temperaturas na germinação de \\ sementes de crambe (Crambe abyssinica Hochst)
}

\author{
Lima Deleon Martins ${ }^{1}$, Felipe Pianna Costa ${ }^{2}$,José Carlos Lopes ${ }^{3}$, Wagner Nunes Rodrigues ${ }^{4}$
}

\begin{abstract}
The objective of this study was to evaluate the influence of pre-germination treatments and temperature on the germination of crambe seed (Crambe abyssinica Hochst). The completely randomized design was used in a $3 \times 3 \times 2$ factorial (physical treatments $\mathrm{x}$ chemical treatments $\mathrm{x}$ temperature). The chemical treatments consisted of paper soaked in gibberellic acid $\left(\mathrm{GA}_{3}\right)$, potassium nitrate $\left(\mathrm{KNO}_{3}\right)$ and water. The physical treatments consisted of maintaining the seed intact, mechanical scarification and seed coat removal. Temperatures of 25 and $30^{\circ} \mathrm{C}$ were used in the completely randomized design. The variables studied were germination speed index, germination percentage, seed length and seedling dry mass. In the studied conditions, the percentage and rate of germination, length and seedling dry weight of seeds of $C$. abyssinica Hochst were enhanced by removal of the integument, in soaking with $\mathrm{GA}_{3}$ at $25^{\circ} \mathrm{C}$.
\end{abstract}

Key words: gibberellic acid, potassium nitrate, seed tegument removal, scarification and temperatures.

\section{RESUMO}

Objetivou-se com o presente trabalho, avaliar a influência de tratamentos pré-germinativos e de temperaturas na germinação de sementes de crambe (Crambe abyssinica Hochst), em esquema fatorial $3 \times 3 \times 2$ (tratamentos químicos $x$ tratamentos físicos $x$ temperatura). Sendo os tratamentos químicos: ácido giberélico $\left(G A_{3}\right)$, nitrato de potássio $\left(\mathrm{KNO}_{3}\right)$ e água. E os tratamentos físicos: semente intacta, escarificação mecânica e a retirada do tegumento. Foram utilizadas as temperaturas de 25 e $30{ }^{\circ} \mathrm{C}$ em delineamento inteiramente casualizado. Estudou-se as seguintes variáveis: índice de velocidade e porcentagem de germinação, comprimento e massa seca das plântulas. Nas condições de estudo, a porcentagem e o índice de velocidade de germinação, o comprimento e a massa seca de plântulas das sementes de C. abyssinica Hochst foram incrementados com a remoção do tegumento, sob o umedecimento com $\mathrm{GA}_{3}$ na temperatura de $25^{\circ} \mathrm{C}$.

Palavras-chave: ácido giberélico, nitrato de potássio, remoção do tegumento, escarificação.

\section{Introduction}

Currently there is a constant search for energy models based on sources of clean and renewable energy such as biodiesel. The oilseed crambe (Crambe abyssinica Hochst), with a grain yield between 1,500 and 1,900 kilograms per hectare and oil content up to $38 \%$, stands out in this scenario due to its great quality for the production of biodiesel. The crambe seed has a spherical shape and is surrounded by a tegument structure called the pericarp (Ruas et al., 2010).

The presence of the pericarp, in some species, can cause irregular or no germination due to the impermeability of the seed coat to water and gases. Thus methods for breaking dormancy are important to monitor the viability of seeds (Alves et al., 2007).

1 Engenheiro Agrônomo, Mestrando em Produção Vegetal, Dep. de Produção Vegetal, Universidade Federal do Espírito Santo, Centro de Ciências Agrárias, Alto Universitário s/n, Caixa Postal 16. 29500-000 Alegre, ES, Brasil.

2 Engenheiro Agrônomo, Mestrando em Produção Vegetal, Dep. de Produção Vegetal, Universidade Federal do Espírito Santo, Centro de Ciências Agrárias, Alto Universitário s/n, Caixa Postal 16. 29500-000 Alegre, ES, Brasil.

3 Engenheiro Agrônomo, D.Sc. em Ciências Biológicas, Dep. de Produção Vegetal, Universidade Federal do Espírito Santo, Centro de Ciências Agrárias, Alto Universitário s/n, Caixa Postal 16, 29500-000 Alegre, ES, Brasil. E-mail: jcufe@ bol.com.br.

4 Engenheiro Agrônomo, M. Sc. Produção Vegetal, Dep. de Produção Vegetal, Universidade Federal do Espírito Santo, Centro de Ciências Agrárias, Alto Universitário s/n, Caixa Postal 16. 29500-000 Alegre, ES, Brasil.

Fecha de Recepción: 22 Diciembre, 2010.

Fecha de Aceptación: 19 Julio, 2012. 
The impermeability can be eliminated, totally or partially, by the structural alteration of the pericarp with methods such as scarification with abrasive material (Alves et al., 2007); sectioning or removal of the seed coat (Costa, Martins \& Lopes, 2010); electrical or pressure treatments (Nascimento, 1982); chemical treatment with sulfuric or hydrochloric acid (Pacheco et al., 2007), bases such as sodium hydroxide (Oliveira et al., 2006), salts such as potassium nitrate (Faron et al., 2004) or organic solvents such as ether, alcohol and acetone (Silva et al., 2011); immersion in water (Ruas et al., 2010); wet or dry heat (Dutra et al., 2007); and even storage (Costa et al., 2012).

Among the methods used to break the dormancy of the tegument, scarification is often used because it is simple, effective and has low cost (Costa, Martins \& Lopes, 2010). However, this technique needs to be performed carefully to avoid damage to the vital tissues of the seed.

In addition to mechanical scarification, soaking seeds in gibberellic acid and potassium nitrate can also increase germination levels and make seedling emergence more uniform. Gibberellin is responsible for the induction of seed germination, and also for the elongation of the hypocotyl and stem (Taiz \& Zeiger, 2004). Potassium nitrate can cause structural changes in the seed, decreasing the influence of the pericarp in water absorption, thereby increasing germination (Faron et al., 2004).

Germination can also be influenced by external factors, temperature being a major factor. Temperature variations affect the speed, rate and uniformity of germination; the optimum temperature is the one that enables the most efficient combination of speed and percentage germination (Marcos Filho, 2005).

The aim of the present study was to evaluate the influence of pre-germination treatments and temperatures on the germination of crambe $(C$. abyssinica Hochst).

\section{Material and Methods}

The experiment was conducted in the laboratory of technology and seed analysis, in the department of crop science of the Centro de Ciências Agrárias of the Universidade Federal do Espírito Santo (CCA-UFES). The seeds of crambe (C. abyssinica Hochst) used in this study were provided by the
MS Foundation, located in Maracujá-MS, from a harvest in October, 2009, which were benefited by eliminating damaged and immature seeds. The water content of the seeds was maintained at $10 \%$; seeds were packed and stored in a refrigerator $\left(3^{\circ} \mathrm{C}\right)$ before the experimental phase.

The chemical treatments were performed in paper soaked in gibberellic acid $\left(\mathrm{GA}_{3}\right)$, potassium nitrate $\left(\mathrm{KNO}_{3}\right)$ and water. The solution concentration used was $500 \mathrm{mg} \mathrm{L}^{-1}$ for $\mathrm{GA}_{3}, 0.2 \%$ for $\mathrm{KNO}_{3}$ and distilled water as control.

The physical treatments consisted of: intact seeds as control; mechanically scarified seeds with manual rubbing on sandpaper $\mathrm{n}^{\circ} 120-59 \mathrm{~B}$; and seeds without tegument whose removal was performed manually with the aid of forceps, without damage to the embryo of the seed.

The experiment studied temperatures of 25 and $30^{\circ} \mathrm{C}$. The plates were kept in BOD type germination chambers, adjusted to $25^{\circ} \mathrm{C}$ and $30^{\circ} \mathrm{C}$, equipped with fluorescent white and cold lights, with 8-16 hours of photoperiod (light-dark) (Brazil, 2009). Each replication contained 25 seeds for each treatment, distributed in Petri dishes with diameter of 11 $\mathrm{cm}$, covered with filter paper with specific weight of $80 \mathrm{~g} \mathrm{~m}^{-1}$ and porosity of $3 \mu$, moistened with 2.5 times the equivalent weight substrate.

The experimental design was completely randomized with 18 treatments and 4 replications, in a factorial scheme $3 \times 3 \times 2$ (chemical treatment $\mathrm{x}$ physical treatment $\mathrm{x}$ temperature). The verification of the proportion of germinated seeds $(\%)$ was performed daily for 12 days, germination being considered effective when primary root protrusions of at least $2 \mathrm{~mm}$ length were observed. During the same period, daily counts were performed to determine the germination speed index (GSI), according to Maguire (1962). After 12 days, the length (SL-cm) and dry mass (SDM-g plant ${ }^{-1}$ ) of the normal seedlings were measured. An engineer's scale was used to measure the hypocotyl and determine seedling length. To obtain the dry mass the seedlings were placed in paper bags and dried in an oven at $70^{\circ} \mathrm{C}$, and after 48 hours weighed in an analytical balance.

The data were subjected to variance analysis $(\mathrm{p} \leq 0.05)$ using the statistical program SISVAR 4.0 (Ferreira, 2008), and the means were compared using the Tukey test $(\mathrm{p} \leq 0.05)$. 


\section{Results and Discussion}

Figure 1 shows the means of germination percentage, germination speed index, seedling length and seedling dry weight obtained for seeds of $C$. abyssinica Hochst influenced by physical treatments for each chemical treatment and temperature.

In general, tegument removal promoted an increase of germination speed, percentage of germination, seedling length and seedling dry weight. The effect of the coat removal was positive, causing higher means in all treatments to break dormancy, using each chemical agent and also for both temperatures (Figure 1).

Similar results were found by Ruas et al. (2010). The authors observed higher germination speed index in crambe seeds without tegument. However, according to Barros et al. (2009), tegument removal of seeds of $C$. abyssinica Hochst did not increase germination, which was similar to that of intact seeds.

This fact occurs because some species have seeds with diminished germination capacity due to the tegument being impermeable because of excessive presence of minerals or the presence of fatty substances (Popinigis, 1985). Thus, despite the fact that the pericarp of the seeds of $C$. abyssinica Hochst being permeable (Ruas et al., 2010), its removal is beneficial because in addition to promoting better contact of the seed directly with water, oxygen and minerals, it can also allow the growth of the embryo without major physical impediments.

Figure 2 shows the means of germination percentage, germination speed index, seedling length and seedling dry weight obtained from seeds of C. abyssinica Hochst influenced by temperature, for each physical and chemical treatment.

Overall, for the variables studied, the temperature of $25^{\circ} \mathrm{C}$ caused higher means compared to $30{ }^{\circ} \mathrm{C}$, for all physical and chemical treatments used to break dormancy (Figure 2). except in the treatment using peeled seeds moistened with $\mathrm{KNO}_{3}$, where the temperature of $30^{\circ} \mathrm{C}$ was more effective, producing higher seedling dry weight in comparison with $25^{\circ} \mathrm{C}$ (Figure 2D).

These results agree with those observed by Panno \& Prior (2009), who found higher values for germination of $C$. abyssinica Hochst at $25^{\circ} \mathrm{C}$.
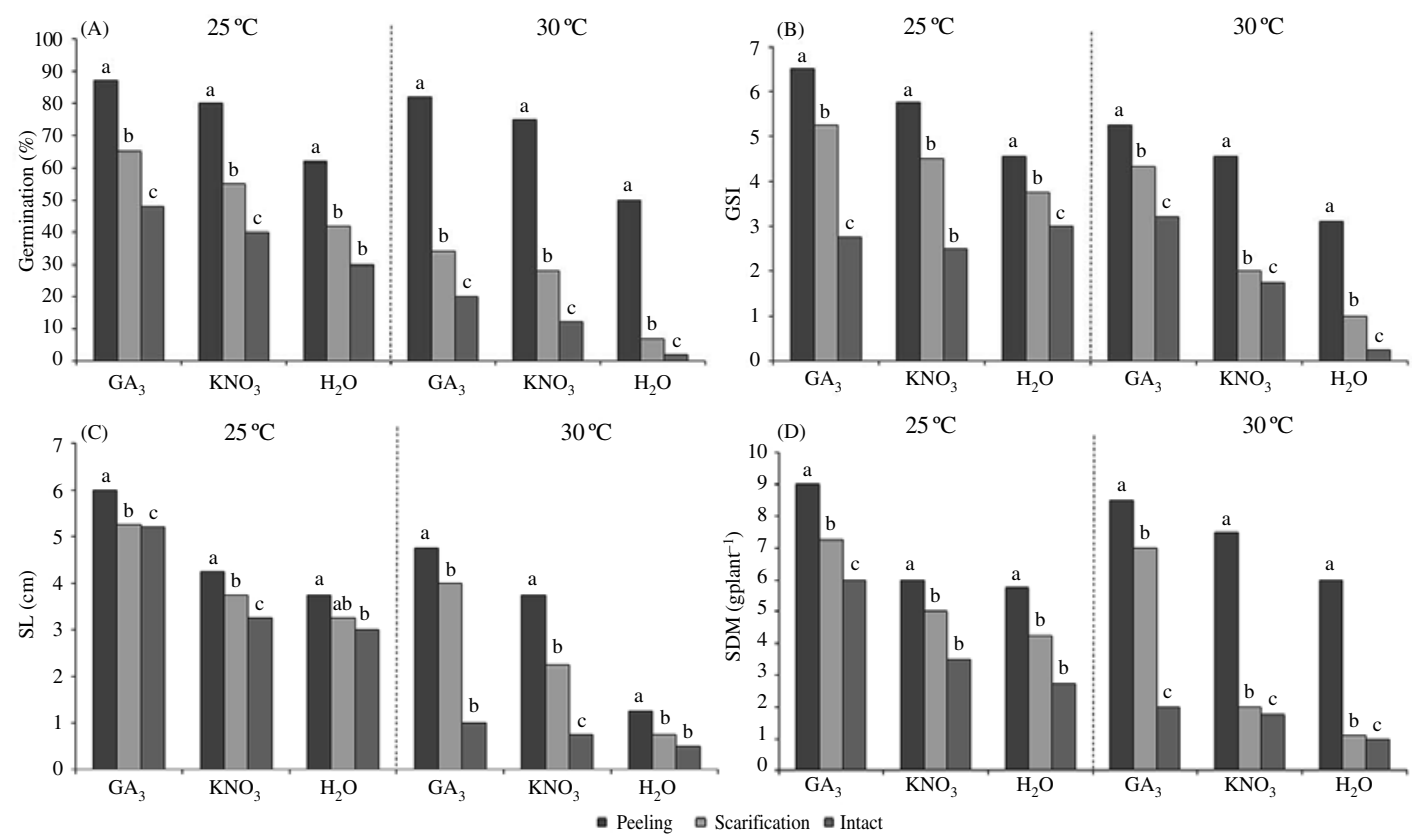

Figure 1. Means of germination percentage (A), germination speed index (B), seedling length (C) and seedling dry weight (D), obtained from seeds of $C$. abyssinica Hochst subjected to different temperatures and chemical methods for breaking dormancy, considering three physical methods (peeling, scarification and intact, respectively).

Means followed by the same letter for each physical treatment, within each chemical treatment and temperature, do not differ by the Tukey test at $5 \%$ probability. 

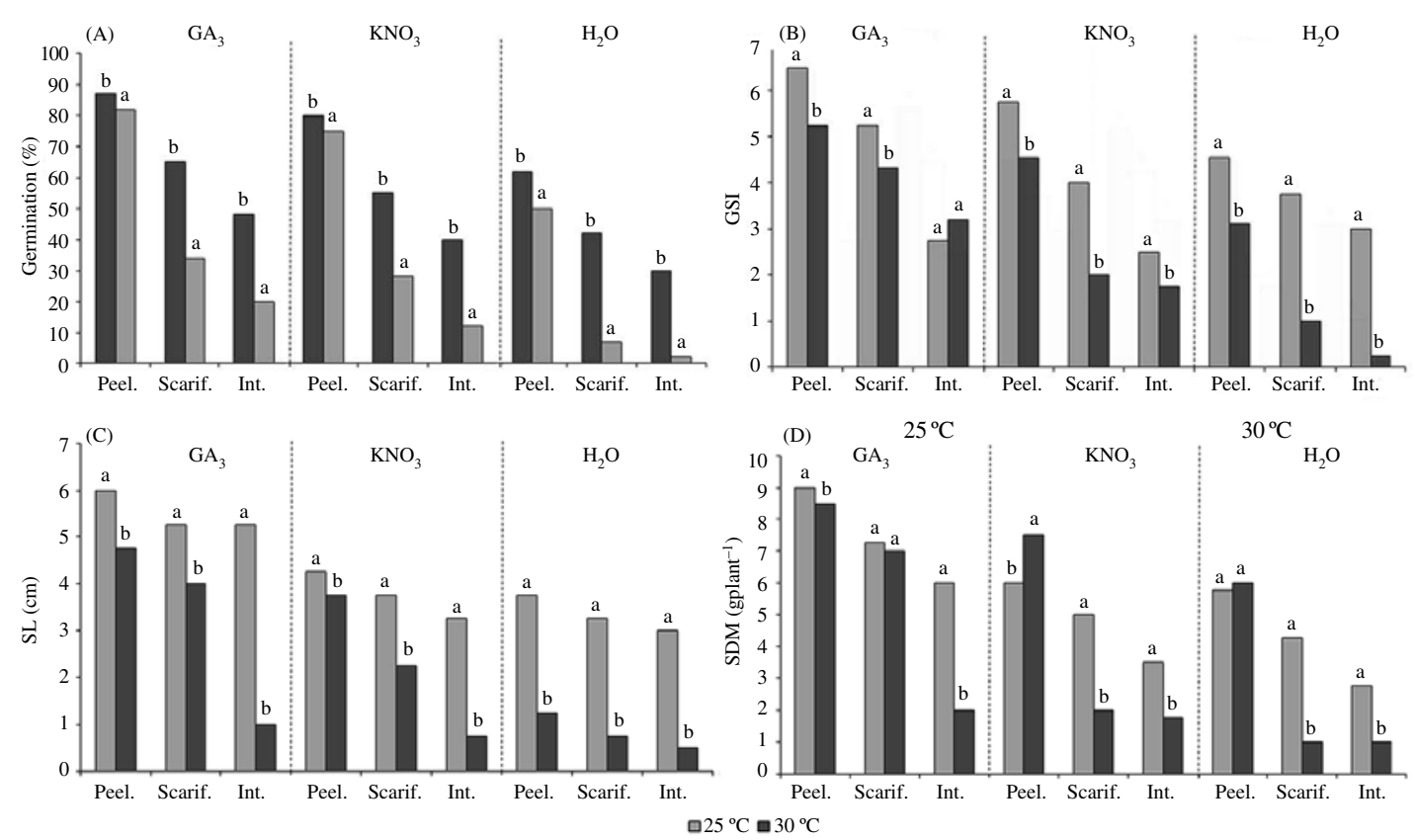

Figure 2. Means of germination percentage (A), germination speed index (B), seedling length (C) and seedling dry weight (D) obtained from seeds of $C$. abyssinica Hochst subjected to physical and chemical methods for breaking dormancy, considering two temperatures $\left(25\right.$ and $30^{\circ} \mathrm{C}$, respectively).

Means followed by the same letter for each temperature, within each chemical and physical treatment, do not differ by the Tukey test at $5 \%$ probability.

By contrast, Santos et al. (2009) found for the same species the best germination percentage at $30^{\circ} \mathrm{C}$, but with low germination speed index. These results confirm those reported by Bewley \& Black (1994), who claimed that the germination process, including germination speed, is affected by temperature.

Seeds have the ability to germinate in a certain temperature range, characteristic for each species. Lower temperatures generally prolong the germination period due to the decreased activity of enzymes involved in metabolism (Carmona \& Martins, 2010). In contrast, excessively high temperatures cause a decrease in the supply of free amino acids, protein synthesis and anabolic reactions, which can denature proteins and change the permeability of membranes (Marcos Filho, 2005).

Studies on the influence of temperature on seed germination and early seedling development are essential to understand the biochemical and ecophysiological aspects of this process (Bewley \& Black 1994).

Figure 3 shows the means of germination percentage, germination speed index, seedling length and seedling dry weight obtained from seeds of $C$. abyssinica Hochst influenced by chemical treatments for each physical treatment and temperature.

In the study of dormancy breaking of seeds of $C$. abyssinica Hochst with chemical agents, the presence of gibberellic acid $\left(\mathrm{GA}_{3}\right)$ in the wetting solution enhanced the germination, germination speed index, seedling length and seedling dry weight, regardless of the physical method employed in both temperatures (Figure 3). Overall, the order of significance was $\mathrm{GA}_{3}>\mathrm{KNO}_{3}>\mathrm{H}_{2} \mathrm{O}$. Except in a few treatments, as in the combination Intact $/ 25^{\circ} \mathrm{C}$ for the variables SL and SDM (Figure $3 \mathrm{C}$ and $3 \mathrm{D}$ ), and also for the combination Intact $/ 30^{\circ} \mathrm{C}$ for GSI (Figure 3B) where the influence of wetting with $\mathrm{GA}_{3}$ and $\mathrm{KNO}_{3}$ were statistically similar.

This result can be explained by the fact that wetting of seeds with gibberellic acid used an endogenous enzymatic activator which affects the protein metabolism of the seed, stimulating the synthesis of enzymes such as alpha amylase, doubling the synthesis rate of proteins in seeds (McDonald \& Khan, 1983) and facilitating the release of energy; this fact influences the resumption 

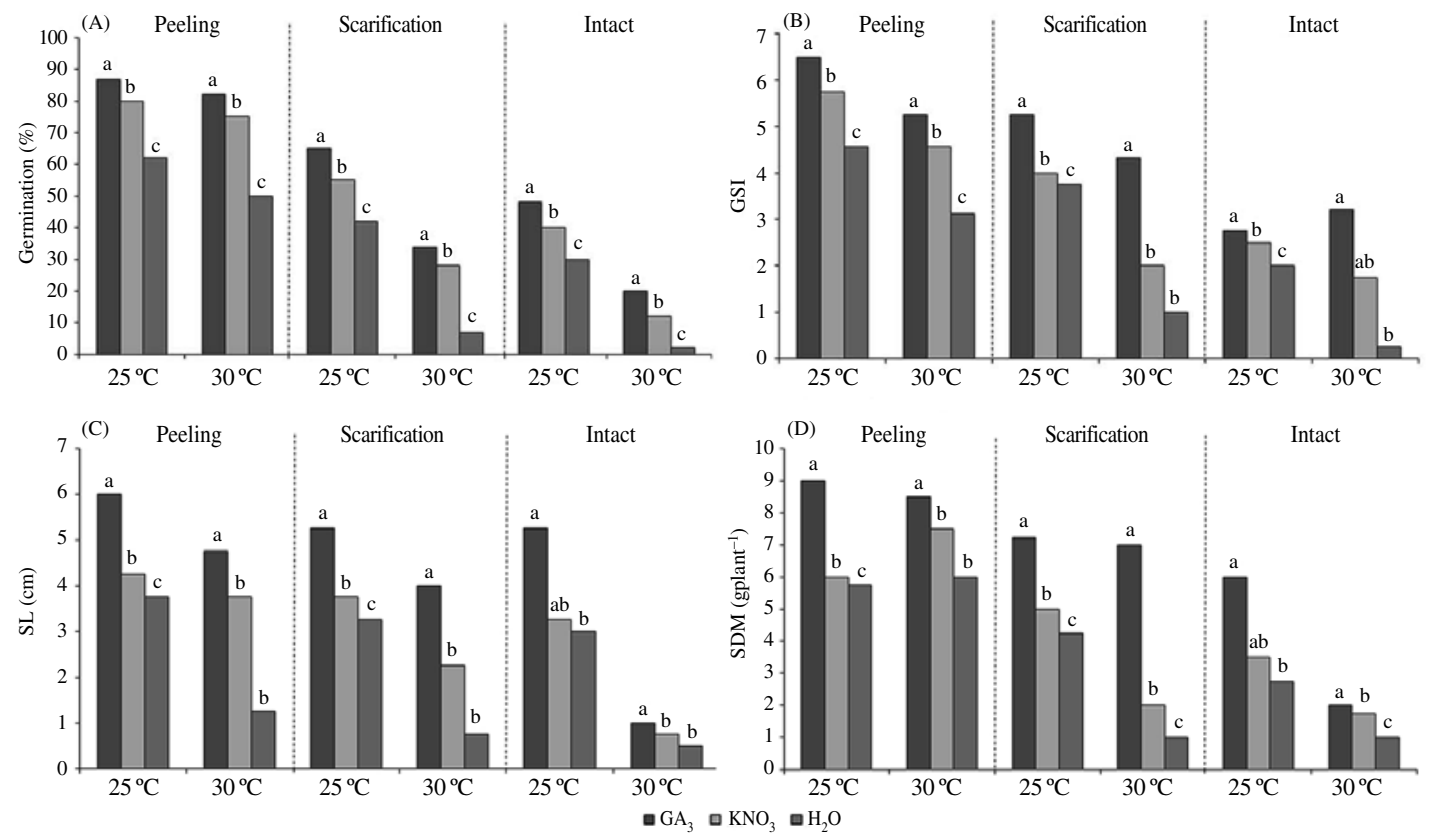

Figure 3. Means of germination percentage (A), germination speed index (B), seedling length (C) and seedling dry weight (D), obtained from seeds of $C$. abyssinica Hochst subjected to different temperatures and physical methods for breaking dormancy, considering three chemical treatments $\left(\mathrm{GA}_{3}, \mathrm{KNO}_{3}\right.$ and $\mathrm{H}_{2} \mathrm{O}$, respectively).

Means followed by the same letter for each chemical treatment within each temperature and physical treatment do not differ by the Tukey test at $5 \%$ probability.

of embryo growth and subsequent germination (Taiz \& Zeiger, 2004).

According to Ferreira et al. (2005), the use of biologically active chemicals such as gibberellic acid can overcome the effects of adverse factors in seed performance and can be used to stimulate the germination even in seeds with tegument.

Lopes \& Souza (2008) and Ferreira et al. (2005) achieved effective results in germination of seeds treated with $\mathrm{GA}_{3}$. According to these authors, the use of gibberellin in the germination phase can improve the vigor and germination of various species, especially under adverse conditions. This confirmation was also reported by Marcos Filho, Barzaghi \& Komatsu (1987) for overcoming seed dormancy in Helianthus annus; this treatment was the most efficient in comparison with other tested methods such as soaking in $\mathrm{KNO}_{3}$, pre-cooling and Ethrel.

For the variables SL and SDM (Figure 3C and 3D) there was effective influence of the treatment with $\mathrm{GA}_{3}$. According to Taiz \& Zeiger (2004), gibberellin promotes cell expansion and also stem and radicle elongation. This effect was observed in the seedlings of $C$. abyssinica Hochst used in this study, causing higher means for seedling length and dry matter, showing that probably the use of gibberellin on germination interferes in later seedling growth.

The wetting of the seeds of $C$. abyssinica Hochst with $\mathrm{KNO}_{3}$ was not effective to break tegumentary dormancy in either the physical treatments or temperatures (Figure 3).

Although $\mathrm{KNO}_{3}$ is used in laboratories to break dormancy of seeds, its mode of action is still debated. The use $\mathrm{KNO}_{3}$ is recommended in species that have coats impermeable to gases, as it is believed that $\mathrm{KNO}_{3}$, on contact with substances in the pericarp decreases the resistance of the coat and facilitates gas exchange (Frank \& Nabinger, 1996).

In some seeds, moistening with $\mathrm{KNO}_{3}$ seems to not work to break dormancy. This was confirmed by Gazziero et al. (1991), testing three concentrations of $\mathrm{KNO}_{3}$ in seeds of Sorghum halepense. These authors reported that none of the tested concentrations of $\mathrm{KNO}_{3}$ enhanced germination. 


\section{Conclusion}

Under the studied conditions, the germination percentage, germination speed index, length and dry weight of seedlings of seeds of C. abyssinica Hochst were increased by the removal of the tegument under moistening with $\mathrm{GA}_{3}$ at $25^{\circ} \mathrm{C}$.

\section{References}

Alves, A.F.; Alves, A.F.; Guerra, M.E.C.; Filho, S.M.

2007. Superação de dormência de sementes de braúna. Revista Ciência Agronômica, v. 38, n. 1, pp. 74-77.

Barros, A.P.B.; Machado, M.F.; Marra, S.H.C.M.

2009. Avaliação de tratamentos para superação de dormência em sementes de crambe Anais.VI Congresso Brasileiro de Plantas Oleaginosas, CD-ROOM.

Bewley, J.D.; Black, M.

1994. Seeds: physiology of development and germination. New York: Plenum, 445 p.

Brasil

2009. Ministério da Agricultura, Pecuária e Abastecimento. Regras para análise de sementes. Brasília: Mapa/ACS. 399 p.

Carmona, R. Martins, C.R.

2010. Dormência e armazenabilidade de sementes de capim-gordura. Revista Brasileira de Sementes, v. 32, n. 4, pp. 071-079.

Costa F. P.; Martins, L. D.; Lopes, J. C.

2010. Frequência de germinação de sementes de crambe (Crambe abyssinica Hochst.) sob influência de tratamentos pré-germinativos e de temperaturas. Nucleus, v. 7 , pp. 185-193.

Costa, L.M.; Osvaldo Resende, O.; Gonçalves, D.N.; Sousa, K.A. 2012. Qualidade dos frutos de crambe durante $o$ armazenamento. Revista Brasileira de Sementes, v. 34, n. 2, pp. 239-301.

Dutra, A.S.; Filho, S.M.; Diniz, F.O.

2007. Dormência, substrato e temperatura para germinação de sementes de albízia. Revista Ciência Agronômica, v. 38, n. 3, pp. 291-296.

Faron, M.L.B.; Perecin, M.B.; Lago, A.A.; Bovi, O.A.

2004. Temperatura, nitrato de potássio e fotoperíodo na germinação de sementes de Hypericum perforatum L. e H. Brasiliense Choisy., v. 63, n. 2, pp. 193-199.

Ferreira, D.F.

2008. SISVAR: um programa para analises e ensino de estatística. Revista Symposium, v. 6, pp. 36-41.

Ferreira, G.; Oliveira, A.; Rodrigues, J.D.; Dias, G.B.

2005. Efeito de arilo na germinação de sementes de Passiflora alata em diferentes substratos e submetidas a tratamentos com giberelina. Revista Brasileira de Fruticultura, v. 27, n. 2, pp. 277-280.

Frank, L.B.; Nabinger, C.

1996. Avaliação da germinação de seis acessos de Paspalum notatum Flügge, nativos do Rio Grande do Sul. Revista Brasileira de Sementes. Brasília, v. 18, n. 1, pp. 102-107.

Gazziero, D.L.P.; Kzryzanowski, F.C.; Ulbrich, A.V.; Voll, E. 1991. Estudo da superação de dormência de sementes de capim massambará através de nitrato de potássio e ácido sulfúrico. Revista Brasileira de Sementes, v. 13, n. 1, pp. 21-25.

Lopes H.M.; Souza, C.M.

2008. Efeitos da giberelina e da secagem no condicionamento osmótico sobre a viabilidade e o vigor de sementes Carica papaya L. Revista Brasileira de Sementes, v. 30, n. 1, pp. 181-189.

Maguire, J.D.

1962. Speed of germination-aid in and evaluation for seedling emergence and vigour. Crop Science, v. 2, n. 1, pp. 176-177.

Marcos Filho, J.

2005. Fisiologia de sementes de plantas cultivadas. Piracicaba, SP: FEALQ, 495 p.

Marcos Filho, J.; Komatsu, Y.H.; Barzaghi, L.

1987. Métodos para superar a dormência de sementes de Helianthus annus L. Revista Brasileira de Sementes, n. 2, pp. 65-75.

Mcdonald, M.D.; Khan, A.A.

1983. Acid scarification and protein synthesis during seed germination. Agronomy Journal, v. 2, n. 75, pp. 111-114.

Nascimento, M.P.S.

1982. Germinação de leguminosas forrageiras nativas submetidas a tratamentos para quebra da impermeabilidade do tegumento. Teresina: Embrapa Meio-Norte, 37 p.

Oliveira, R.P.; Scivittaro, W.B.; Radmann, E.B.

2006. Escarificação química da semente para favorecer a emergência e o crescimento do porta-enxerto Trifoliata. Pesquisa Agropecuária Brasileira, v. 41, n. 9, pp. 1429-1433.

Pacheco, M.V.; Matos, V.P.; Barbosa, M.D.; Ferreira, R.L.C.

2007. Germinação de sementes de Platypodium elegans Vog. submetidas a diferentes tratamentos pré-germinativos e substratos. Revista Brasileira de Engenharia Agrícola e Ambiental, v. 11, n. 5, pp. 497-501.

Panno, G.; Prior, M.

2009. Avaliação de substratos para a germinação de Crambe abyssinica. Cultivando o saber, v. 2, n. 2, pp. 151-157.

Popinigis, F.

1985. Fisiologia da semente. Brasília, DF: Agiplan, 289 p.

Ruas, R.A.A.; Nascimento, G.B.; Bergamo, E.P.; Júnior, R.H.D. 2010. Uniformizando a germinação na cultura do Crambe abyssinica. Pesquisa agropecuária tropical, vol. 40, n. 1, pp. 90-105.

Santos, H.O.S.; Araújo, J.C.; Marchese, A.; Carvalho, M.L.M. 2009. Comportamento de sementes de Crambe abssynica Hochst submetidas a diferentes temperaturas e condições de luz. Anais.VI Congresso Brasileiro de Plantas Oleaginosas, CD-ROOM.

Silva, P.E.M.; Santiago, E.F.; Daloso, D. M.; Silva, E. M.; Silva, J.O.

2011. Quebra de dormência em sementes de Sesbania virgata (Cav.) Pers. Revista IDESIA, Arica-Chile. v. 29, n. 2, pp. 39-45.

Taiz, L.; Zeiger, E.

2004. Fisiologia vegetal. 3. ed. Porto Alegre: Artmed, 719 p. 